\title{
Investigation of Multi-Pesticide Residues in Prunus persica L. (peach) Cultivars of District Swat Using Gas Chromatography-Mass Spectroscopy
}

\author{
Muhammad Amin ${ }^{1,2}$, Ali Raza Gurmani ${ }^{1 *}$, Fayaz Ali², Shah Masaud Khan', \\ Abid Farid', Muhammad Shakur ${ }^{3}$, Waqar Khan ${ }^{4 * *}$ \\ ${ }^{1}$ Department of Soil and Climate Sciences, Faculty of Basic and Applied Sciences, University of Haripur, Pakistan \\ ${ }^{2}$ Shaheed Benazir Bhutto University Sheringal, Dir Upper, Pakistan \\ ${ }^{3}$ Department of Plant Protection, Agriculture University Peshawar, Pakistan \\ ${ }^{4}$ State Key Laboratory of Crop Genetics and Germ Plasma Enhancement, Centre of Pear Engineering Technology \\ Research, Nanjing Agriculture University, Nanjing 210095, China
}

Received: 29 May 2021

Accepted: 30 August 2021

\begin{abstract}
Protection of agricultural crops from pests and diseases is very important to fulfill the needs of growing population. For this purpose, different types of chemicals are used which leads to the accumulation of toxic organic and inorganic compounds in agricultural cycle particularly in economically important fruits and vegetables. Pesticide residue analysis is fundamentally important to ensure the safety of foods, plant and animal origin, and to preserve the environment. It is therefore crucial to monitor fruits and vegetables for pesticide residues using available advanced analytical techniques. The current study was assigned to investigate pesticide residues in peach fruit. We selected six peach cultivars (Early Grand, Florida King, NJC (05), Elberta (06), Maria Delezia, and Indian blood) from four different locations of district Swat. The sampled fruit varieties were then analysed for pesticide residues using gas chromatography and mass spectroscopy (GC-MS). Results showed that Early Grand variety had pesticide residues with highest concentration of Cypermethrin $\left(16.7 \pm 1.38 \mu \mathrm{g} \mathrm{kg}^{-1}\right)$ followed by Pyridaben $\left(7.425 \pm 0.11 \mu \mathrm{g} \mathrm{kg} \mathrm{kg}^{-1}\right)$. In Florida King, the highest $\mathrm{c}$ oncentration of Endosulfan $\left(32.78 \pm 0.9 \mu \mathrm{g} \mathrm{kg}^{-1}\right)$ is detected followed by Metachlore $\left(17.36 \pm 0.44 \mu \mathrm{g} \mathrm{kg}^{-1}\right)$. In variety NJC and Elberta, Pyredaben, Propachlor, Carbofuran, Cypermethrine, Endosulfan, and Cyhalothrine compound were found. In both varieties, Endosulfan was in the highest concentration $\left(21.27 \pm 1.20 \mu \mathrm{g} \mathrm{kg}^{-1}\right.$ and $67.94 \pm 4.61 \mu \mathrm{g} \mathrm{kg}{ }^{-1}$ respectively). As these two varieties had close harvesting time, both varieties showed a similar pattern of pesticide residues. In variety Maria, Difenaconazole was found in the highest concentration $\left(187.51 \mu \mathrm{g} \mathrm{kg}^{-1}\right)$ while the Indian blood variety difenaconazole
\end{abstract}

\footnotetext{
*e-mail: ali.gurmani@uoh.edu.pk

**e-mail: waqar.khan399@gmail.com
} 
was noted with the highest concentration $\left(88.60 \pm 8.9 \mu \mathrm{g} \mathrm{kg}^{-1}\right)$. The Chloropyrifos was not detected in any variety and the possible reason may be, it is applied at flowering stage before fruit initiation. Although all cultivars at different locations had pesticide residues, however it cannot be considered a serious public health problem because compounds and their residual levels were below critical concentration as defined by European Union regulations. Furthermore, judicious use of pesticides in fruit and vegetable would certainly ensure their minimal exposure in products.

Keywords: Prunus persica L., pesticides, mass spectrometry, gas chromatography

\section{Introduction}

Agriculture and horticulture sectors share more than $20 \%$ of its gross domestic product (GDP), providing an opportunity of employment to $67.5 \%$ population of Pakistan [1]. These sectors help in improving the life styles of individual of rural areas linked to agriculture [2]. Vegetables and fruits are the important components of horticulture crops across the globe due to its consumption rate. Pakistan is an agriculture country and it exports different fruits (Apple, Peach, Mango, Oranges, etc.), vegetables (Turnips, Carrots, Radish, Cabbages etc.) to United Arab Emirates, India, Afghanistan, Saudi Arabia, United Kingdom and China etc. to earn valuable foreign exchange [3]. Apart from nutritional and economic value, fruits also provide important antioxidants to reduce toxic substances produced as a result of metabolic activities in cell [4]. These antioxidants offers resistance to certain human diseases like cardiac disorders, diabetes mellitus, neurodegenerative diseases and cancer etc. [5].

Agriculture revolution has increased the chemical burden on natural environment, of which, pesticides is widely used agrochemicals to protect crops [6]. On the other hand, these pesticides are very hazardous to environment due to their potential of causing adverse effects both to living and non-living components. Since several pesticides have been linked to health and environmental problems, they have been phased out of use [7]. Chemical pesticides have been related to a range of negative health effects, including dermatological, gastrointestinal, neurological, carcinogenic, respiratory, reproductive, and endocrine effects [8]. Pesticides enter to living system either through direct contact, ingestion, or inhalation. The type of pesticide, its duration, the route of exposure, and the individual's health status (e.g. nutritional deficits and healthy/damaged skin) all influence the risk of harmful health impacts [7]. Pesticide residues can be present in a wide range of daily foods and drinks, such as cooked meals, water, wine, fruit juices, snacks, and animal feeds [9].

Climatic condition of Pakistan favours growth (production) of vegetables, fruits and other ornamental plants [10]. The fruit sector had excellent development in the last few decades. Among which, peach is believed the "Queen" of fruits having very next position to apple in terms of popularity. Fresh peach is comprised of very healthy nutrients, good source of vitamins (A and C) and also contains potassium and fibres. In Pakistan, atmosphere of Khyber Pakhtunkhwa (KP) favours the peach cultivation. Land over 950 meters above the sea level is an ideal for nurturing of peach plant. It is grown in northern areas of KP, of which Swat, Peshawar, Parachinar, Chitral, and Hazara are very prominent. District Swat of KP yields high quality of peach fruit in Pakistan [11].

Pesticide residues in food are rapidly increasing causing significant health implications and therefore, attract global attention [12]. The resurgence of pests, soil, water and air pollution, annihilation of predators, parasites and other non-target species exposes the adverse effects on ecological systems inextricably linked to human health [13]. In Pakistan, over 108 insecticides types, 30 fungicides, 39 weedicides, 5 acaricides, and 6 rodenticides are currently in use [14]. Misuse of pesticides leads to financial losses as well as health risks. The current level of pesticides in the environment (soil, water, and air) helps to measure its impact on human health $[15,16]$. The present work was designed, to provide base-line data on status of pesticide residues level in the peach fruit samples from different locations of district Swat. This study will also help in determination of toxicity level of pesticides in fruits.

\section{Materials and Methods}

In Pakistan, district Swat is very popular due to its greenery producing a number of edible fruits. In the current study, peach cultivars from 4 of sub-divisions of district Swat (i.e. Matta, Khwaza Khela, Kabal, and Barikot) (Fig. 1) were selected for determination of pesticide residues. 6 peach cultivars were selected from each sub division namely: Early Grand (EG), Florida King (FK), NJC (05), Elberta (06), Maria Delezia (MD), and Indian Blood (IB). Each variety was collected from individual sub division during 2018. A total of 24 fresh fruits composite samples were collected from different peach orchards in district Swat for pesticide residues analysis. We evaluate pesticides residues in the collected mature fresh peach fruit samples from farmer's orchards.

\section{Reagents Used}

Sigma-Aldrich provided acetonitrile (HPLC grade), 


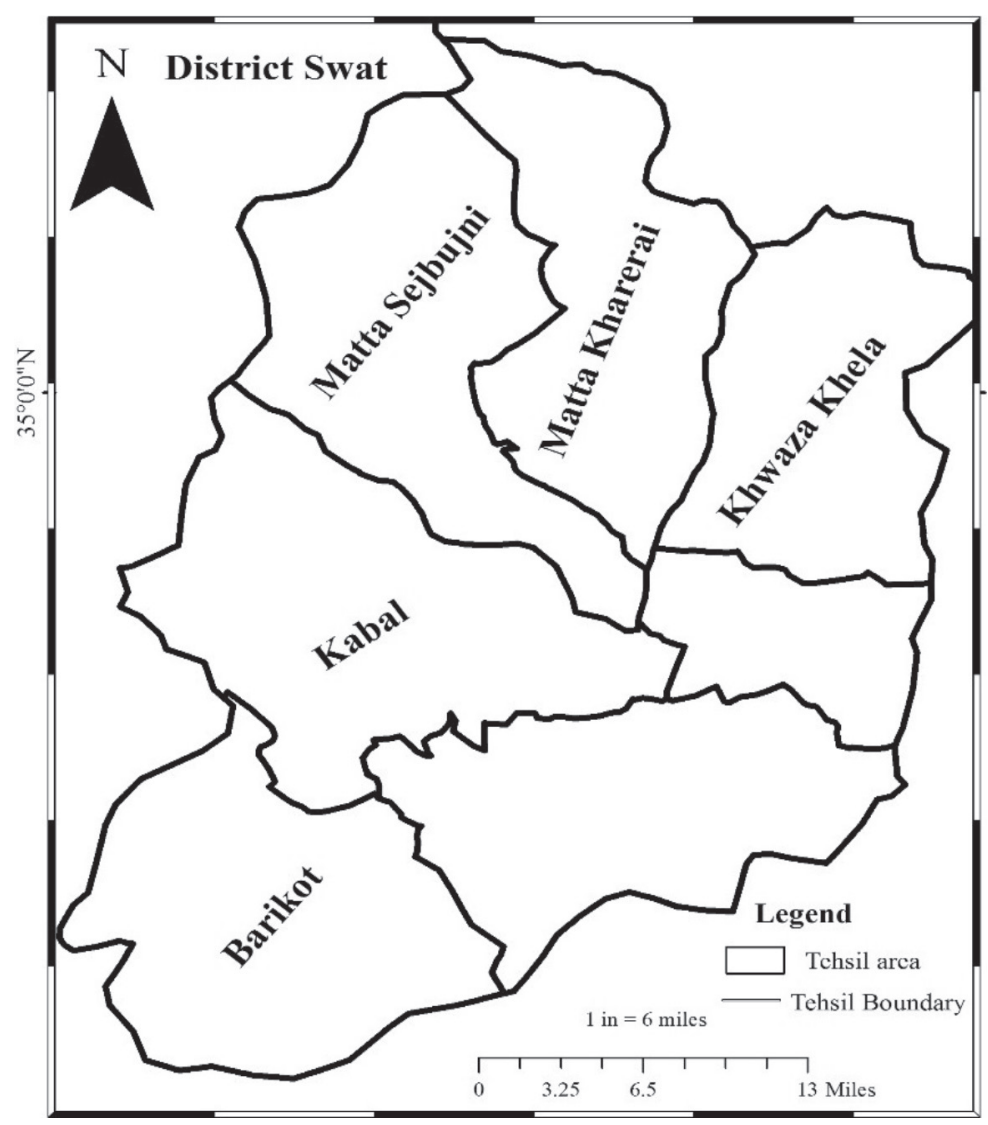

Fig. 1. Map of the study area.

anhydrous magnesium sulphate $(99.5 \%)$, glacial acetic acid, anhydrous sodium acetate $(99.5 \%)$, primarysecondary amine (PSA), and $\mathrm{NaCl}$ (Germany). All of the chemicals used in the experiment were analytical grade.

\section{Samples Preparation}

Collected fruit samples from the farmer's orchards were placed in polythene bags and labelled properly. Samples were then kept in ice box, and brought to the Pakistan Council of scientific and Industrial Research Complex, Peshawar. The samples were stored in $4^{\circ} \mathrm{C}$, than chopped into smaller pieces for extraction of pesticides residues QuEChERS (Quick, Easy, Cheap, Effective, Rugged and Safe) following standard method of Albinet et al. [17].

\section{Extraction}

Aliquot $(8 \mathrm{ml}), 1.2 \mathrm{~g}$ of $\mathrm{MgSO}_{4}$ and $50 \mathrm{mg}$ sorbent (Primary secondary amine) were added to extract. The extract tube was then vertex and centrifuged for 1 minute at $3500 \mathrm{rpm}$.

Volume of extract was then reduced to $0.3-0.5 \mathrm{ml}$ by removing the excess solvent using rotary evaporator $\left(50^{\circ} \mathrm{C}\right.$ and reduced pressure). Next toluene was added to make final volume $1 \mathrm{ml}$. For drying, $1.2 \mathrm{~g}$ anhydrous $\mathrm{MgSO}_{4}$ were added to extract and then swirl to settle down solid materials. The supernatant was filtered by $0.45 \mu \mathrm{m}$ membrane and transferred the aliquot to $\mathrm{GC}$ vial for analysis on $\mathrm{GC}-\mathrm{MS}$.

\section{GC-MS Analysis}

A Shimadzu QP 2010 plus gas chromatography -mass spectrometry system (Kyoto, Japan) was used for the study. An SE 30 capillary column (50 m $0.25 \mathrm{~mm}$ ID at $0.25-\mathrm{m}$ film thickness) was used for separation. The temperature program for the column was set to begin at $50^{\circ} \mathrm{C}$ and hold for 1 minute, then gradually increase to $300^{\circ} \mathrm{C}$ and hold for 10 minutes. At a column flow of $1 \mathrm{ml} \mathrm{min}-1$, the carrier gas was helium (99.999 percent). The interface and injection were set to $250^{\circ} \mathrm{C}$ to break a 11 injection into two sections. For the determination of selected pesticides, an ion monitoring mode with electron effect ionization was used.

\section{Results and Discussion}

The determination of pesticides residues in peach fruit was carried out Pakistan Council of Scientific and Industrial Research Laboratories, Peshawar. Information regarding extent of pesticide application for different varieties of peach samples was obtained from local farmers. The selection of peach varieties was based upon their popularity and high consumption 
Table 1. Different Peach varieties containing pesticide residues $\left(\mu \mathrm{gKg}^{-1}\right)$.

\begin{tabular}{|c|c|c|c|c|c|c|}
\cline { 1 - 5 } Varieties & \multirow{2}{*}{ Early grand } & Florida King & NJC (05) & Elberta (06) & Maria Delezia & Indian blood \\
\cline { 1 - 5 } Compounds detected & & & & & & \\
\cline { 1 - 5 } Pyridaben & $7.425 \pm 0.11$ & $13.8 \pm 2.5$ & $24.25 \pm 2.15$ & $22.3 \pm 0.82$ & $28.50 \pm 4.06$ & $11.29 \pm 3.12$ \\
\hline Chloropyrifos & $0 \pm 0$ & $0 \pm 0$ & $0 \pm 0$ & $0 \pm 0$ & $0 \pm 0$ & $0 \pm 0$ \\
\hline Propachlor & $2.94 \pm 0.42$ & $1.15 \pm 0.4$ & $0.81 \pm 0.46$ & $1.54 \pm 0.85$ & $4.10 \pm 0.75$ & $5.16 \pm 0.87$ \\
\hline Carbofuran & $1.74 \pm 0.12$ & $12.39 \pm 1.06$ & $0 \pm 0$ & $15.21 \pm .01$ & $4.21 \pm 0.09$ & $17.45 \pm 0.81$ \\
\hline Metachlore & $0 \pm 0$ & $17.36 \pm 0.44$ & $0 \pm 0$ & $0 \pm 0$ & $0 \pm 0$ & $18.0 \pm 0.77$ \\
\hline Cypermethrine & $16.7 \pm 1.38$ & $4.47 \pm 2.01$ & $4.14 \pm 1.49$ & $3.56 \pm 0.55$ & $2.28 \pm 0.32$ & $1.85 \pm 0.52$ \\
\hline Dichlorovos & $2.27 \pm 0.29$ & $2.11 \pm 0.91$ & $0 \pm 0$ & $0 \pm 0$ & $0 \pm 0$ & $2.31 \pm 0.05$ \\
\hline Endosulfan & $0 \pm 0$ & $32.78 \pm 0.9$ & $21.27 \pm 1.20$ & $67.94 \pm 4.61$ & $18.41 \pm 1.18$ & $10.39 \pm 1.48$ \\
\hline Cyhalothrine & $0 \pm 0$ & $15.32 \pm 1.13$ & $14.51 \pm 0.11$ & $0 \pm 0$ & $0 \pm 0$ & $34.8 \pm 1.03$ \\
\hline Difenaconazloe & $0 \pm 0$ & $0 \pm 0$ & $0 \pm 0$ & $0 \pm 0$ & $88.60 \pm 8.9$ & $107.4 \pm 4.2$ \\
\hline Acetamprid & $0 \pm 0$ & $0 \pm 0$ & $0 \pm 0$ & $0 \pm 0$ & $0 \pm 0$ & $90.02 \pm 2.47$ \\
\hline
\end{tabular}

rates by indigenous population of KP. Different types of pesticides are being used in order to control pest infestation in food crops. The results of the current study indicate that toxins are absorbed in fruits, where metabolizing enzymes are responsible for their bioactivation and detoxification. The toxicity of different pesticides and insecticides like Chlorpyrifos (CPF) and diazinon (DZN) can be mediated through metabolism to CPF-oxon and DZN-oxon, respectively [18]. These toxic chemicals can also be detoxify to trichloropyridinol (TCP) and 2-isopropyl-4-methyl-6-hydroxypyrimidine
(IMHP) $[19,20]$. Physiologically based pharmacokinetic/ pharmacodynamic (PBPK/PD) models have been developed for the Organophosphorus (OP) like Chlorpyrifos (CPF), Metolachlor (Met), Profenofos (Prfe) and Diazinon (DZN) etc. It is anticipated that these OPs could interact at a number of important metabolic steps including: CYP450 mediated activation/ detoxification, B-esterases carboxylesterase $(\mathrm{CaE})$, butyrylcholinesterase $(\mathrm{BuChE})$ and acetylcholinesterase (AChE) or PON-1 (A-esterase) oxon detoxification $[21]$.
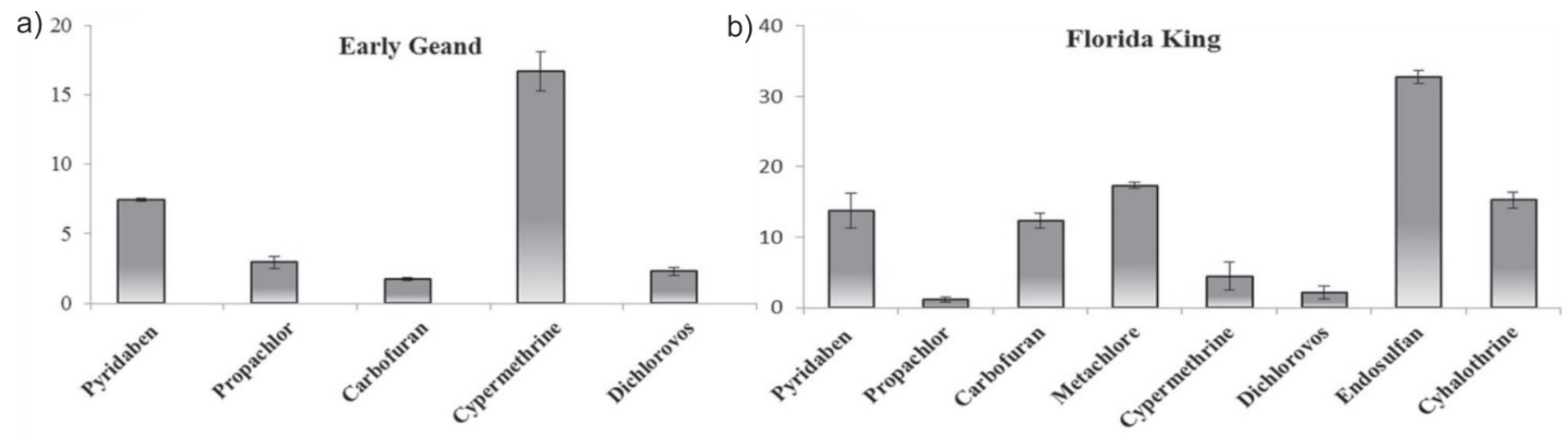

c) 30

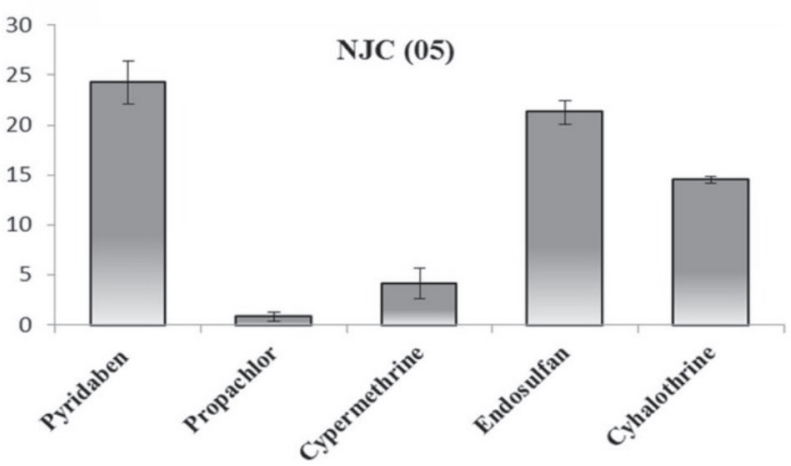

Fig. 2. Pesticides residues in various cultivars of peach: Early Grand a), Florida King b), and NJC-05 c). 
Table 2. GC-MS instrument calibration with the standard pesticides.

\begin{tabular}{|c|c|c|c|c|c|c|}
\hline Name of the compound & Retension time & Area & LOD & LOQ & $\mathrm{R}^{2}$ & $Y=a+b x$ \\
\hline Aldicarb deg & 3.46 & 303263 & 0.09 & 0.31 & 0.997 & $6545 X-295$ \\
\hline Methamidophos & 6.40 & 740971 & 0.07 & 0.25 & 0.998 & $15699 X-519$ \\
\hline Dichlorovos & 6.46 & 800123 & 0.04 & 0.14 & 0.999 & $14042 X-446$ \\
\hline Carbofuran deg. & 7.06 & 22574 & 0.19 & 0.65 & 0.990 & $604 X-10$ \\
\hline Metolcarb & 8.82 & 1059299 & 0.04 & 0.13 & 0.999 & $20807 X+232$ \\
\hline Propachlor & 10.41 & 997615 & 0.01 & 0.06 & 0.999 & $19635 X+212$ \\
\hline Carbofuran & 11.85 & 118382 & 0.07 & 0.23 & 0.998 & $2182 X-141$ \\
\hline Atrazine & 11.99 & 187875 & 0.10 & 0.33 & 0.997 & $4045 X-167.67$ \\
\hline Acetochlor & 13.45 & 262899 & 0.27 & 0.89 & 0.982 & $6779 X-961.67$ \\
\hline Metribuzin & 13.57 & 132571 & 0.26 & 0.87 & 0.983 & $3385 X-460$ \\
\hline Methiocarb Sulfoxide & 13.94 & 4755 & 0.02 & 0.06 & 0.999 & $114 \mathrm{X}+4.33$ \\
\hline Metolachlor & 14.63 & 1453128 & 0.24 & 0.81 & 0.985 & $36570 X-4929.33$ \\
\hline Chloropyrifos & 14.68 & 190666 & 0.30 & 1.01 & 0.978 & $4855 X-621.67$ \\
\hline Aldrine & 14.80 & 145268 & 0.20 & 0.67 & 0.989 & $3694 X-567.67$ \\
\hline Pendimethalin & 15.58 & 123348 & 0.24 & 0.82 & 0.984 & $3901 X-550$ \\
\hline Alpha endosulfan & 16.92 & 46174 & 0.29 & 0.98 & 0.978 & $1221 X-192.33$ \\
\hline Profenofos & 17.45 & 295149 & 0.20 & 0.68 & 0.989 & $7640 X-1276$ \\
\hline $\mathrm{p}, \mathrm{p}$ DDE & 17.57 & 317812 & 0.24 & 0.81 & 0.984 & $8340 X-1398$ \\
\hline Beta Endosulfan & 18.77 & 24757 & 0.28 & 0.93 & 0.980 & $675 X-125$ \\
\hline Acetamiprid & 21.65 & 70817 & 0.13 & 0.45 & 0.995 & $2245 X-258.33$ \\
\hline Cyhalothrine I & 23.18 & 60776 & 0.24 & 0.81 & 0.985 & $1905 X-209.67$ \\
\hline Cyhalothrine II & 23.51 & 206316 & 0.25 & 0.84 & 0.983 & $4691 X-799.67$ \\
\hline Pyridaben & 25.28 & 770168 & 0.23 & 0.76 & 0.986 & $19155 X 2406.7$ \\
\hline Cypermethrine I & 26.66 & 41545 & 0.24 & 0.82 & 0.984 & $1389 X-218.33$ \\
\hline Cypermethrine II & 26.96 & 123198 & 0.31 & 1.05 & 0.976 & $2550 X-275.33$ \\
\hline Fenvalerate I & 28.36 & 71844 & 0.23 & 0.78 & 0.986 & $1542 X-226$ \\
\hline Fenvalerate II & 28.76 & 49303 & 0.17 & 0.58 & 0.991 & $1318 X-277$ \\
\hline Difenaconazole I & 29.22 & 116223 & 0.18 & 0.63 & 0.990 & $2881 X-329.33$ \\
\hline Difenaconazole II & 29.347 & 122589 & 0.075 & 0.250 & 0.998 & $2476 X+29.667$ \\
\hline
\end{tabular}

Gas chromatography-electron capture detection recorded $0.04-0.25 \mu \mathrm{g} / \mathrm{kg}$ of 11 pesticides residues. The recoveries of the 11 pesticides in the vegetable and fruit samples were $81.5-111 \%$ with the relative standard deviations less than $11.2 \%$ [22]. Similarly pesticides residues detection in 85 fruits and vegetables shows recovery $81 \%$ of pesticides through GC-MS [23]. Linear calibration curves for studied pesticides were obtained with correlation coefficients $\left(\mathrm{r}^{2}\right)$ between 0.985 and 0.999 . The LOD were ranges from 0.018 to $0.317 \mathrm{mg} \mathrm{kg}^{-1}$ while the level of quantification ranged from 0.060 to $1.058 \mathrm{mg} \mathrm{kg}-1$. The levels of pesticide residues found in collected samples are presented in Table 1. Eleven pesticides i.e. Pyridaben (Pyr), Chlorpyrifos (CPF), Propachlor (Pro), Carbofuran (Car), Metachlore (Met), Cypermethrine (Cyp), Dichlorovas (Dic), Endosulfan (End), Cyhalothrine (Cyh), Difenaconazole (Dif), and Acetamaprid (Ace) were found at levels between $0.81 \mu \mathrm{g} \mathrm{kg}^{-1}$ and $107.4 \mu \mathrm{g} \mathrm{kg}^{-1}$ (Table 1). The transport behaviour of Propachlor in the presence of thiosulfate was found to be relatively complex compared to traditional conservative or single-constituent tracers. Using thiosulfate to reduce the emissions of pesticides at the soil surface and as a soil remediation methodology [24]. 
a)

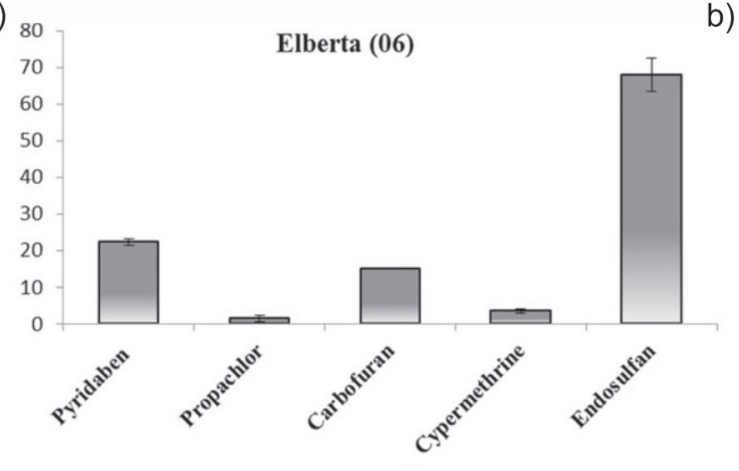

b) 120

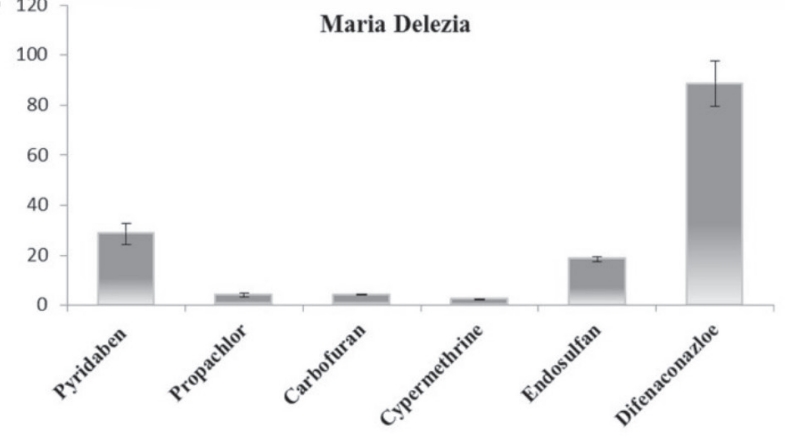

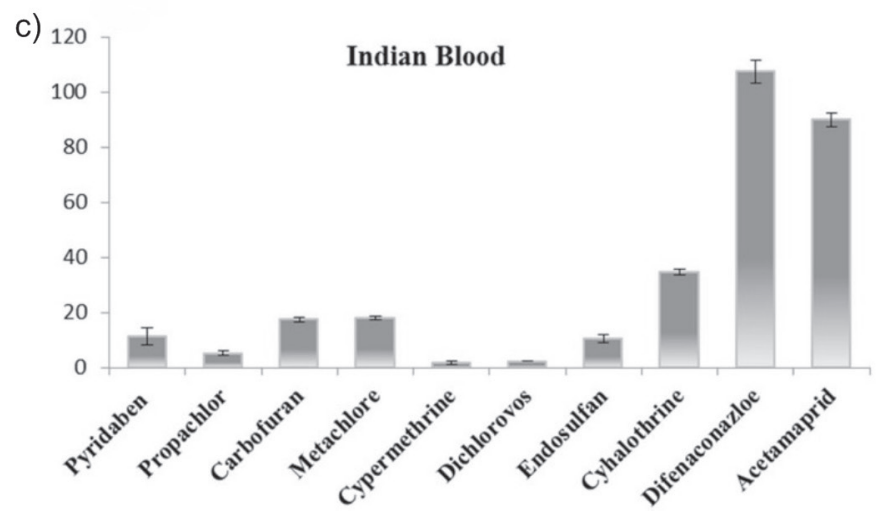

Fig. 3. Pesticides residues in various cultivars of peach: Elberta-06 a), Maria Delezia b), and Indian Blood c).

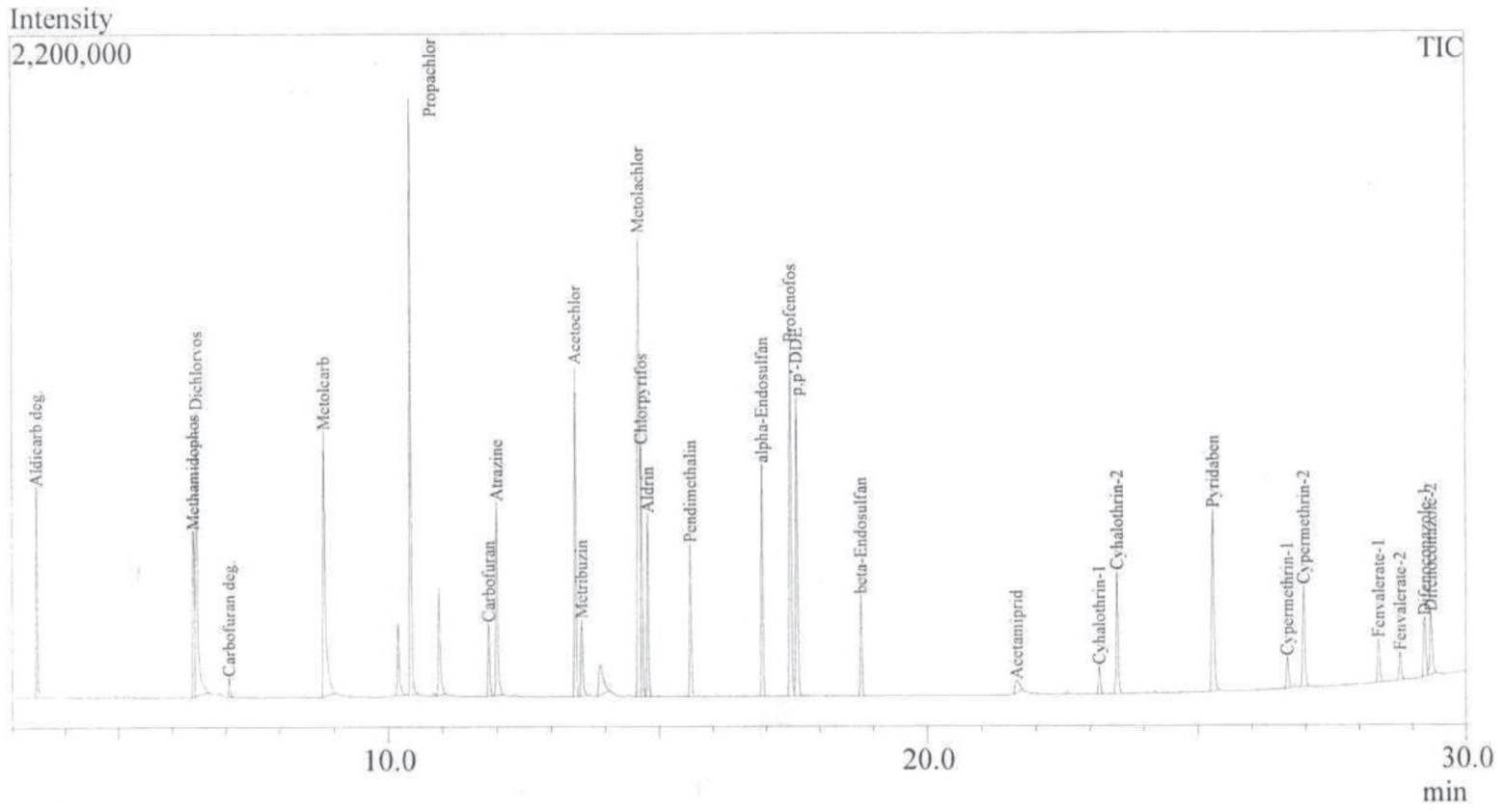

Fig. 4. GC-MS chromatogram of the Standard Pesticides.

The detection area ranged from $0.78 \mathrm{mg} / \mathrm{mL}$ to $50.0 \mathrm{mg} / \mathrm{mL}$ was recommended fit for the demand of quantitative determination of Pro residue in plant productions [25]. Cross-reactivity indicated that the antiserum could only react with Metalaxyl and its acid, but not Met, Diethatyl-ethyl, Alachlor Pro, or Benzoylprop-ethyl, whose structures are similar to
Metalaxyl [26, 27]. Current data showed that majority of residues monitored were in concentrations below maximum residual limit (MRL). The increased selectivity of GC-MS reduces effect of matrix, and thus reduces limits of detection (LOD) ranged from $0.81 \mu \mathrm{g} \mathrm{kg}^{-1}-107.4 \mu \mathrm{g} \mathrm{kg}{ }^{-1}$ lower than MRL (Fig. 4). Sample preparation methods that have been proposed 
to date for extraction of neonicotinoids might remain in a complicated sample matrix with lesser quantity for cleaning up, the interfering components that coexist in the sample extract [28]. In the present study, EG variety contained Pyr, Pro, Car, Cyp and Dic pesticide residues with highest concentration of Cyp $16.7 \pm 1.38 \mu \mathrm{g} \mathrm{kg}^{-1}$ followed by Prop $7.425 \pm 0.11 \mu \mathrm{g} \mathrm{kg}^{-1}$, while other pesticides residues were low and not hazardous to human health (Fig. 2a). In FK, Pyr, Pro, Car, Met, Cyp, Dic, End, and Cyh were detected. Among these, the highest concentration of End $32.78 \pm 0.9 \mu \mathrm{g} \mathrm{kg}^{-1}$ was detected followed by Cyh $15.32 \pm 1.13 \mu \mathrm{g} \mathrm{kg}^{-1}$ (Fig. 2b).

In variety $\mathrm{NJC}-05$ and variety Elberta-06, Pyr, Pro, Car, Cyp, End and Cyh were detected. Pyr $\left(24.25 \pm 2.15 \mu \mathrm{g} \mathrm{kg}^{-1}\right)$ was recorded maximum for NJC-05 followed by End $\left(21.27 \pm 1.20 \mu \mathrm{g} \mathrm{kg}^{-1}\right)$, while the Pro was ranked the last with $0.81 \pm 0.46 \mu \mathrm{g} \mathrm{kg}^{-1}$ amount of residues (Fig. 2c). Unlike to NJC-05, the amount of End was $\left(67.94 \pm 4.61 \mu \mathrm{g} \mathrm{kg}^{-1}\right)$ maximum for Elberta-06, while in same there was no residue of CPF, Met, Dic, Cyh, Dif and Ace (Fig. 3a). As these two varieties have similar harvesting time, therefore both varieties had a similar pattern of pesticide residues. Similar results for pesticides residues in peach fruits were reported by [29]. In variety MD, Pyridaben, Propachlor, Carbofuran, Metachlore, Cypermethrin, Endosulfan and Difenaconazole were detected. Among these compounds, Difenaconazole was detected in highest concentration $\left(88.60 \pm 8.9 \mu \mathrm{g} \mathrm{kg}^{-1}\right)$ in comparison to other pesticides (Fig. 3b).

The Indian blood variety was contaminated with the Pyridaben, Propachlor, Carbofuran, Metachlore, Cypermethrine, Dichlorovos, Endosulfan, Cyhalothrine, Difenaconazole, and Acetamaprid except Chloropyrifos (Fig. 3c). Generally. Chloropyrifos was not detected among all the mentioned varieties because Chloropyrifos was sprayed at dormant period when plants had no fruits. Similar results were reported for Chloropyrifos in peaches in Pakistan [30]. Current study significantly correlates with results of [31]. Comparison of pesticides residues in different varieties showed that early varieties have less extent of pesticides residues as compared to late fruiting varieties. The present study showed that current contamination level cannot be considered as a serious public health problem according to EU regulations. To prevent pesticides exposure, it is necessary to reduce and monitor use of pesticides in fruit and vegetable products. Nevertheless, pesticide residue monitoring programs are appropriate to ensure minimal residue levels in products [32].

\section{Conclusion}

The present study was conducted to investigate the pesticides residues in different peach cultivars fresh fruits. The result revealed that the early fruiting cultivars have less amount of pesticides residues as compared to the late fruit producing cultivars. All cultivars at different locations had pesticides residues; however, it cannot be considered a serious public health problem because the compounds and their residual levels were below critical concentrations as defined by European Union regulations. Furthermore, judicious use of pesticides in fruit and vegetable would certainly ensure their minimal exposure in products.

\section{Conflict of Interest}

The authors report no conflicts of interest.

\section{References}

1. SYED J.H., ALAMDAR A., MOHAMMAD A., AHAD K., SHABIR Z., AHMED H., ALI S.M., SANI S.G.A.S., BOKHARI H., GALLAGHER K.D., AHMAD I. Pesticide residues in fruits and vegetables from Pakistan: a review of the occurrence and associated human health risks. Environmental Science and Pollution Research, 21 (23), 13367, 2014.

2. POPKIN B.M., ADAIR L.S., NG S.W. Global nutrition transition and the pandemic of obesity in developing countries. Nutrition reviews, 70 (1), 3, 2012.

3. ARIF M.J., WAKIL W., GOGI M.D., KHAN R.R., ARSHAD M., SUFYAN M., NAWAZ A., ALI A. AND MAJEED S. Trends in Sustainable Management of Emerging Insect Pests. Developing Sustainable Agriculture in Pakistan, 417, 2018.

4. BJØRKLUND G., CHIRUMBOLO S. Role of oxidative stress and antioxidants in daily nutrition and human health. Nutrition, 33, 311, 2017.

5. LIGUORI I., RUSSO G., CURCIO F., BULLI G., ARAN, L., DELlA-MORTE D., GARGIUlO G., TESTA G., CACCIATORE F., BONADUCE D., ABETE P. Oxidative stress, aging, and diseases. Clinical interventions in aging, 13, 757, 2018.

6. CONNELL D.W., LAM P., RICHARDSON B., WU R. Introduction to ecotoxicology. John Wiley \& Sons. 2009.

7. ALEWU B., NOSIRI C. Pesticides and human health. Pesticides in the Modern World - Effects of Pesticides Exposure. InTech, 231, 2011.

8. THAKUR D.S., KHOT R., JOSHI P.P., PANDHARIPANDE, M. AND NAGPURE, K. Glyphosate poisoning with acute pulmonary edema. Toxicology international, 21 (3), 328, 2014.

9. CHOURASIYA S., KHILLARE P.S., JYETHI D.S. Health risk assessment of organochlorine pesticide exposure through dietary intake of vegetables grown in the periurban sites of Delhi, India. Environmental Science and Pollution Research, 22 (8), 5793, 2015.

10. ZIA M.S., KHAN M.J., QASIM M., REHMAN A. Pesticide residue in the food chain and human body inside Pakistan. J. Chem. Soc. Pak, 31 (2), 284, 2009.

11. KHALIL I., IDREES M., RABI F., REHMAN S., BOSTAN N., An investigation into the problems of peach growers in district swat. Journal of Agricultural and Biological Science, 9, 427, 2014. 
12. MESNAGE R., SÉRALINI G.E., Toxicity of pesticides on health and environment. Frontiers in public health, 6, 268, 2018.

13. NICOLOPOULOU-STAMATI P., MAIPAS S., KOTAMPASI C., STAMATIS P., HENS L. Chemical pesticides and human health: the urgent need for a new concept in agriculture. Frontiers in public health, 4, 148, 2016.

14. ANWAR,T.A.H.I.R., AHMAD I., TAHIR S.E.E.M.A. Determination of pesticide residues in fruits of Nawabshah district, Sindh, Pakistan. Pak J Bot, 43 (2), 1133, 2011.

15. SHAMMI M., SULTANA A., HASAN N., RAHMAN M.M., ISLAM M.S., BODRUD-DOZA M., UDDIN M.K. Pesticide exposures towards health and environmental hazard in Bangladesh: A case study on farmers' perception. Journal of the Saudi Society of Agricultural Sciences, 19 (2), 161, 2020.

16. AHMAD I., ANWAR T. Pesticide residues in fruits and vegetables and their impact on human health. Magazine, Horticultural Society of Pakistan, 57, 49, 2007.

17. ALBINET A., TOMAZ S., LESTREMAU F. A really quick easy cheap effective rugged and safe (QuEChERS) extraction procedure for the analysis of particle-bound PAHs in ambient air and emission samples. Science of the total environment, 450, 31, 2013.

18. PROSKOCIL B.J., GRODZKI A.C.G., JACOBY D.B., LEIN P.J., FRYER A.D. Organophosphorus pesticides induce cytokine release from differentiated human THP1 cells. American journal of respiratory cell and molecular biology, 61 (5), 620, 2019.

19. SCARPONI L., VISCHETTI C., HASSAN N.M. Effects of propachlor on the formation of carbohydrates and proteins in Vicia faba and the response of its defence mechanism. Agrochimica (Italy), 2002.

20. FAN X. Function and Regulation of Intestinal Cytochrome P450, 2019.

21. REFFSTRUP T.K. Evaluation of Methodologies for Risk Assessment of Combined Toxic Actions of Chemical Substances and Establisment of PBTK/TD Models for Pesticides: Ph. D. Thesis. Division of Toxicology and Risk Assessment, Technical University of Denmark, 2012.

22. WANG M., ZHOU X., ZANG X., PANG Y., CHANG Q., WANG C., WANG Z. Determination of pesticides residues in vegetable and fruit samples by solid-phase microextraction with a covalent organic framework as the fiber coating coupled with gas chromatography and electron capture detection. Journal of separation science, 41 (21), 4038, 2018.
23. HADIAN Z., ESLAMIZAD S., YAZDANPANAH H. Pesticide residues analysis in Iranian fruits and vegetables by gas chromatography-mass spectrometry. Iranian journal of pharmaceutical research: IJPR, 18 (1), 275, 2019.

24. SOUZA L.R.R., POMAROLLI L.C., DA VEIGA M.A.M.S. From classic methodologies to application of nanomaterials for soil remediation: an integrated view of methods for decontamination of toxic metal (oid) s. Environmental Science and Pollution Research, 27 (10), 10205, 2020.

25. GAO S., QIN R., MCDONALD J.A., HANSON B.D., TROUT T.J. Field tests of surface seals and soil treatments to reduce fumigant emissions from shank injection of Telone C35. Science of the total environment, 405 (1-3), 206, 2008.

26. MCDONALD J.A., GAO S., QIN R., TROUT T.J., HANSON B.D. Thiosulfate and manure amendment with water application and tarp on 1,3-dichloropropene emission reductions. Environmental science \& technology, 42 (2), 398, 2008.

27. YATES S., PAPIERNIK S., BROWN G.E. March. Fate and transport of propachlor and thiosulfate. In abstracts of papers of the American Chemical Society 225, pp. U94-U94. 1155 16TH ST, NW, WASHINGTON, DC 20036 USA: AMER CHEMICAL SOC, 2003.

28. WATANABE E. Review of sample preparation methods for chromatographic analysis of neonicotinoids in agricultural and environmental matrices: From classical to state-of-theart methods. Journal of Chromatography A, 462042, 2021.

29. SUNGUR Ş., TUNUR, Ç. Investigation of pesticide residues in vegetables and fruits grown in various regions of Hatay, Turkey. Food Additives and Contaminants: Part B, 5 (4), 265, 2012.

30. SAMAD A., AKHTAR S., SHAHID M.M., AHAD $\mathrm{K}$. Determination of pesticide residues in peaches by using gas chromatography and mass spectrometric detection. International Journal of Environmental Analytical Chemistry, 99 (14), 1446, 2019.

31. TAHIR H.A., GU Q., WU H., RAZA W., HANIF A., WU L., COLMAN M.V., GAO X. Plant growth promotion by volatile organic compounds produced by Bacillus subtilis SYST2. Frontiers in Microbiology, 8, 171. 2017.

32. HANDFORD C.E., ELLIOTT C.T., CAMPBELL K. A review of the global pesticide legislation and the scale of challenge in reaching the global harmonization of food safety standards. Integrated environmental assessment and management, 11 (4), 525, 2015. 